\title{
Leisure Activities of Female Foreign Workers in Taiwan: Transnationalism, Feminism and Work Arrangements
}

\author{
Chiung-Tzu Lucetta Tsai \\ National Taipei University \\ E-Mail: cttsai@gm.ntpu.edu.tw
}

\begin{abstract}
The number of foreign workers in Taiwan is increasing. As a result, such workers' leisure activities outside of the workplace have become a strong area for research on work and leisure. In terms of transnationalism, feminism, and work arrangements, this study proposes to examine the leisure activities of female foreign workers. The aim of the study has three aspects: first, to examine to what extent transnationalism and feminism operate to influence the leisure activities of female foreign workers, respectively; second, to explore how work arrangements influence the leisure activities of female foreign workers and their managerial implications; and third, to understand if public and private leisure provisions are enough to meet the demands of female foreign workers. The findings of this research will not only contribute to the formation of the public and private leisure provisions and the management of female foreign workers, but will also fill the gap in research on 'work and leisure.'
\end{abstract}

Keywords: Leisure, Foreign Workers, Transnationalism, Feminism, Work Arrangements

\section{INTRODUCTION}

The number of foreign workers in Taiwan has increased year by year. The leisure time of these foreign workers provides an optimal backdrop for foreign workers' work-and-leisure related research on the basis of creating foreign workers' life management policy. To help foreign workers adapt to living in Taiwan, the leisure life of foreign workers has been identified as a focus of the management policy of foreign workers at all levels of government, in addition to requiring business units to organise foreign labour leisure activities and requiring key administrations to include a budget to promote foreign labour leisure activities. At the end of October 2010, statistics revealed 
that the total number of blue-collar foreign workers in Taiwan was 373,190 people, while the number of female foreign workers was 226,326, which accounted for $60.6 \%$ of the total number of foreign workers (Council of Labour Affairs, 2010). The total number of professional foreign workers (or white-collar foreign workers) was 27,478, while the number of professional female foreign workers was 4,987, which accounted for $18.1 \%$ of the total number of professional foreign workers (Council of Labour Affairs, 2010). For example, the 2010 Bureau of Employment and Vocational Training, Council of Labour Affairs, through the Employment Security Fund, listed more than USD \$2.2 million in funding for foreign worker management counselling (including provision of leisure activities), which accounted for $18 \%$ of total annual funding for the management of foreign workers (Council of Labour Affairs, 2010). However, opportunities to engage in leisure activities for blue-collar foreign workers after work are still lacking. In a survey on the use and management of foreign workers by the Council of Labour Affairs (2007), the portion regarding foreign workers in public institutions revealed that $24.31 \%$ belonged to cultural and recreational centres, $19.04 \%$ had arrangements for holiday leisure activities, 26.56\% had counsellors provided for leisure and work, and $12.33 \%$ were a part of life counselling groups. The portion pertaining to home care workers had no leisure-related statistics. However, from the content of their work, daily working hours, and holiday situations, we can roughly estimate the leisure time and opportunities outside of work by the type of labour. In the job content, 'physical and mental disabilities care' accounted for the majority, with $56.0 \%$, '24-hour care of the disabled' came in second place and accounted for $45.6 \%$, 'helping with housekeeping' accounted for 37.4\%, and 'care of children' accounted for only $2.0 \%$. Among these workers, 59.3\% perform only one kind of work, 36.7\% perform two kinds of work, and 3.9\% perform three kinds, revealing that $40 \%$ of foreign care workers still need to perform other work. For daily working hours, 87.5\% were 'without stipulation' in the labour contract, and $12.5 \%$ 'with stipulation.' Whereas, for employers who did not stipulate working hours, foreign caregivers' actual working hours per day were 9.5 on average; this figure rose to 13.5 working hours on average if stipulated. Regarding the holiday situation, 'no holiday' accounted for a 51.1\% majority.

Employer mismanagement, poor allocation of labour and leisure, poor working conditions, and other factors led to issues of escaping foreign workers, becoming a dead-end for Taiwan's security and immigration affairs. The escaping foreign workers are often victims of human trafficking (Wu, 2006; Wu, 2008). For example, the U.S. State Department, in its Taiwan 'Human Trafficking Report' published in recent years, stated the following: 
Taiwan is the destination of the trafficking of men, women, and children mainly for forced labour and sexual exploitation... A considerable number of male and female foreign workers (mainly from Vietnam, Thailand, and the Philippines), through legal employment in Taiwan, engage in the construction, fishing, and manufacturing industries, in low-skilled jobs, or as domestic helpers... The process of the recruitment of 340,000 foreign workers and the placement of these people in Taiwan (half of whom are as domestic helpers or as homecare workers in private homes, which are not protected by labour laws in Taiwan) lack supervision and monitoring so that it may lead to the situation of involuntary servitude. (U.S. Department of State,2007).Some employers of domestic helpers or homecare workers prohibit workers to leave home outside of vacation time, so these workers easily become victims of labour trafficking and other abuses and are unable to seek help.(U.S. Department of State, 2010).The U.S. State Department's annual report helps us focus on the management and leisure issues of foreign workers before concentrating on the human trafficking of foreign workers. In terms of foreign workers' management and counselling, Taiwan provided $18 \%$ of the total annual foreign workers management funding. The Foreign Workers Employment and Management Group of the Bureau of Employment and Vocational Training of the Council of Labour is responsible for the implementation. A responsible unit or competent department for management or services of foreign workers was also set up within the bureaus (department) of labour in the city and county governments, which also included the leisure of foreign labourers as an important government project. For example, important duties of the Labour Department of Taipei County include 'conducting recreational activities for foreign workers,' and the duties of the Labour Department of the Yunlin County Government include 'organising and conducting recreational activities for foreign workers.' However, because of foreign workers' management problems, Taiwan in recent years was ranked by the U.S. State Department in its annual 'Human Trafficking Report' as the country that engaged in the most human trafficking of foreign workers. Female foreign workers upon escaping often become the object of commercial sexual exploitation and forced labour. For the study of foreign workers in Taiwan, human resources or labour relations scholars often focus on foreign labour and employment issues (i.e. Hsin, 2007; Wu, 2008). Sociologists and background scholars are often concerned about the social situation and class culture of foreign workers (i.e. Lin \& Lin, 2008; Wu, 2002; Wu, 2006; Tseng, 2004; Lan, 2002 \& 2006). Other concerns include the economy (for example, Chiang, 2006), human rights (Wang \& Juan, 2007; Soong \& $\mathrm{Su}, 2008$ ), and policy issues (for example, Hsu, 2006; Chiao, 2005). In the leisure areas, few studies were concerned with labour or female leisure issues, and more were only correlated (Tsai, 2008 \& 2009; Yeh, 2008; Chung, et al., 2008; Chang et al., 2007). 
Cross-ethnic studies of leisure activities in female foreign workers not only help to understand the views of foreign female workers from all races on Taiwan leisure space, but also help to identify the types of leisure activities foreign female workers of different races in Taiwan are engaged in, as well as potential limitations. This study is grounded in the perspectives of 'feminism,' 'cross-nationalism,' and 'work arrangement.' The findings not only contribute to the development of public and private leisure and foreign labour management measures and policies, but also make up for the dearth of knowledge in the academic sector pertaining to 'labour' and 'leisure' areas.

\section{THEORETICAL BACKGROUND: WORK, LEISURE \& CROSS-NATIONALISM}

Leisure is defined as non-work activities during free time, and the standard of classification revolves around the nature of activities, which is different from work (Neulinger, 1981). Psychological perspectives on leisure focus on questions such as: How much leisure does one need? What importance does leisure play in the development of the personality? (Field et al., 2011) The boundary between 'labour' and 'work' in present society is extremely vague and often interchangeable. Work can sometimes be combined with leisure in discussions, and at other times the concepts appear far apart from each other. Edginton and Coles (2009) described the relationship between work and leisure as a spill over, or compensatory. Work will shape a person's personality and individuality, and one's character will also be shaped during leisure time, so no strict boundaries exist between work and leisure (Chou et. al., 2007; Yang et. al., 2010). Leisure can make up for a feeling of dissatisfaction at work and other experiences and attitudes of work, with leisure forming the opposite relationship. In addition, because of the limited resources of time and energy, leisure and work mutually consume fixed resources, so they form a competition. Parker (1983) added the concept of 'neutrality' to the relationship between the two.

Neutrality emphasises the independence of work and leisure. There is no correlation between the experience and attitude of work and leisure. But the neutral model is not a compromise of the first two. Rather, it emphasises that leisure is not passively attached to work, but is, rather, independent. Each person's leisure patterns will differ under various social conditions. Under different circumstances, the relationship between work and leisure has different interpretations, because different forms of social organisation are involved. As a result, until we gain a clear understanding of the organisational form of an activity, we cannot determine it to be work or leisure. The concept of foreign workers' cross-nationalism was proposed by Van Domelen et al. (2011), who believed that a new type of immigrant population was 
rising and that it contained the networks, activities, and lifestyles of those people from their home countries as well as their country of residence. Their lives penetrate the national territory and convert the two societies into a wholly unique social field. A new concept is therefore needed to define the experiences and awareness of these recent immigrants. We call this new concept 'cross-nationalism.' Monika and Santos (2006), in their study of cross-nationalism and leisure activities of American Mexican temporary migrant workers, found that the impact of temporary Mexican migrant workers in the United States in terms of which leisure behaviours they engaged in can be summarised into four core elements: a particular family's status, unique work arrangements, socioeconomic and cultural networks, and the unique legal status. A particular family's status refers to the responsibility to be undertaken by migrant workers for family members; unique work arrangements mainly involve the type of work, time for work and rest, shift situations, labour-intensive or knowledge-oriented kinds of work, etc. Socioeconomic and cultural networks refer to the social situation, economic situation, and racial and cultural context; and unique legal status refers to the situation of foreign workers being protected by labour laws or immigration laws in their country of residence. The four core factors that affect foreign workers are helpful in the construction of the relationship between labour and leisure under the concept of cross-nationalism. Female blue-collar foreign workers in Taiwan not only overcome the patriarchal structure and management of the workplace, but also discrimination against foreign workers in the community or treatment as a person of low class (Lin, 2000; Liu, 2001; Wu, 2002). In a study of foreign maids from the Philippines, Lan (2006) showed that these female foreign maids made up for the psychological distress of discrimination or unfair treatment in the workplace through shopping on holidays and trendy attire (tight T-shirts, miniskirts, designer jeans, nail polish, earrings, etc.), which differed from the 'pretence to be unattractive' in the workplace, so as to show themselves off, shirk off the obedient, unflattering, and self-restraining side of work, and escape from employer monitoring. Tseng's (2004) study found that 'class' lies at the forefront of Taiwan's foreign labour management policies and Taiwanese views on foreign workers, and that the introduction of foreign workers in Taiwan is mostly in low-end, low-wage labour, where racism and the doctrine of class combine to form a racial doctrine of class. This racial doctrine of class has resulted in foreign workers confronting inappropriate management structures in order to be able to access opportunities for recreation (Jiang, 2006). 


\section{METHODOLOGICAL APPROACH}

In the survey of female foreign workers, according to their labour patterns, the fields of blue-collar foreign workers include: industry (such as traditional manufacturing industries), home (such as domestic workers and care workers), and female agency workers (such as workers in nursing homes) in the country's classification. Blue-collar foreign workers encompass the Taiwanese government's opening up to major countries, such as the Philippines, Vietnam, Thailand, Indonesia and Cambodia.This study views the output of its leisure activities research from the perspective of cross-nationalism and feminism, with female foreign workers' labour patterns as the intervening variable. The structure of respondents included interviewees from six different nationalities and female blue-collar workers of different labour patterns. Therefore, in-depth interviews were adapted in this study.Through second-hand data, including magazines (Next Magazine, Business Today, The Journalist) and newspapers (United Daily News, Apple Daily, China Times and The Liberty Times), the observations of cross-nationalism versus global female leisure activities (attending major events and parties of Townsmen Association of Vietnam, Indonesia, The Philippines, Thailand and Cambodia), the correlation between labour patterns and leisure activities, a collection of data pertaining to the discussion of leisure issues in feminism was conducted. Based on the empirical data obtained from a study of 30 female foreign workers from the Philippines, Vietnam, Thailand, Indonesia, and Cambodia, and through comparative analysis of domestic and overseas literature, an understanding of cross-country leisure behaviour, feminism orientation, and the degree of impact by the foreign labour patterns of female foreign workers from these five countries was gained. By way of critical thinking, cases of similarities and differences and common trends and differing trends were identified as a basis for the field study. Leisure activities under the concept of cross-nationalism created by female foreign workers from Indonesia, the Philippines, Thailand, Cambodia and Vietnam in different working modes (factories, social welfare institutions, and the home) are presented, while analysis of the impact of feminism on female foreign workers engaged in leisure activities is observed. The findings and discussions of this study are helpful in the life management and leisure planning of female foreign workers, and in the formulation of foreign labour management policy. In-depth interviews were conducted with female blue-collar foreign workers representing different working modes of female blue-collar workers from the Philippines, Vietnam, Thailand, Indonesia and Cambodia, and other Southeast Asian nations. In total, 23 interviews were completed. In the interview sampling, special attention was paid to the age distribution of female foreign workers as it related to the women's life circle. In terms of interview sources, industrial female 
foreign workers were recommended by the personnel department of industry, which employs foreign workers; while home and agency female foreign workers were recommended by the foreign workers affairs inspectors of the county government, by fellow associations, or by immigration agencies. The analysis of data for this study was intricately linked from the commencement of data collection. An initial concern in the data analysis was whether to use computer programmes such as NVivo. The benefits of using such programs are many: they can aid the researcher in developing multiple categories and pursuing alternative analytical themes. However, access to and instruction in NVivo was problematic, in that the time required to develop the required skills to achieve a useful level was time consuming. Instead, more traditional methods of refining themes in the data were adopted. Research ethics is concerned with achieving clarity regarding the nature of the agreement the researcher has entered into with the research subjects. Ethical research involves obtaining the informed consent of those whom the researcher is to interview, question, or observe (Blaxter et al., 1996). Because these respondents volunteered to participate in the study, confidentiality had to be guaranteed. In the interview, confidentiality refers to the data collected from informants being held in confidence. The issue of confidentiality lies in what promises the researcher makes to the informants in the course of data collection (Kimmel, 1988). It is important that the interviewee knows that she or he is being interviewed and that the information she or he provides will be used for research. Therefore, the obligations for these interviews are that the information will be treated with confidentiality and anonymity unless an interviewee's express agreement stipulates otherwise. In the course of the interview process, additional crucial ethical issues pertain to the identification of the researcher, confidentiality and legality (Kimmel, 1988). Whether to declare the identification of the researcher reflects a dilemma between covert and overt research, and debate on the two methods of gaining access to research has been controversial.

\section{FINDINGS AND DISCUSSIONS}

The women's needs and wants for leisure provisions do not have an immediate effect on society and living conditions, but women have discovered that in terms of the association between their own preferences and leisure supplies, their hopes and expectations cannot be met, thus resulting in the forced retention of the society the women strive to change. This force will affect women's willingness to participate in leisure activities, which often makes women feel that they are surrounded by personal and social constraints when they want to participate freely in leisure (Edginton et al., 2011; Payne et al., 2010). As one Vietnamese respondent put it: 
Our Vietnamese girls' leisure activities do not include sports; our leisure is simply chatting over coffee for several hours. Only overweight girls need exercise. It is very strange to see girls run and jump like boys, as this is not our culture. Being too masculine will be looked down upon by boys. Leisure education has a certain importance, but women's leisure has been greatly repressed. Its correlation is subject to cultural values, which not only limit the ability of women's self-awareness but also distort social values. Through the establishment of human values and the advocacy of positive leisure concepts, education can be a means of improvement, nurturing the concept of equal rights for men and women. Women with higher educations will quickly enhance women's leisure rights, and this represents a type of educational influence on social mobility. Women with higher educations not only have the driving force to actively pursue leisure, but also enjoy higher statuses in leisure areas. The relative lack of recreational sports resources for women is primarily due to the fact that men are usually high-ranking in this area. Because of this patriarchal influence, not to mention the fact that the vast majority of resources and development are focused on men, women's leisure is thus oppressed. As one Cambodian respondent states:

I began to work after graduating from junior high school. Working hours are long. Since coming to Taiwan, I get up at five in the morning to make breakfast for the boss's family and work till nine at night before getting rest. However, there is a holiday on Sunday; I can go out, but I do not know any sports. I did not learn swimming or playing ball in my hometown, so I can only go shopping to pass the time. In the use of public space, the public has given a more lenient standard to men. Going out every day of the week for leisure is not often criticised. On the other hand, when women go out two or three days in one week, they might quickly be deemed as not taking care of their family life. Double standards exert greater pressure on women, leading to their reluctance to leave home to go to public areas for leisure activities (Tsai, 2006; Karp et al., 2010; Tsai, 2010a). An Indonesian respondent states:

I cut chicken in the processing plant all day, and when I go home I still have to help the children with their homework, even though my Chinese is poor. My husband scolds me and loses his temper in front of the children, who then get scared and cry. He goes out every night with friends, but I stay at home and have no leisure. However, in my hometown I would have to do farming, so there is no rest there either. I thought that it would be very easy in Taiwan. In fact, there is not much difference. Married women or women with partners are encouraged to participate in leisure activities with their spouses: first, to give the public a good impression, and second, to meet the male desire to control. At least keeping the other half by their side will be less likely to result in unethical acts; it can also be described as a certain degree of chauvinism. If women 
want to go to the pub or public places for a social dance, they are mostly limited by elders and social recognition, so men often prohibit this activity or accompany women to participate, but if they accompany the women, it also tends to signify declaration of sovereignty, so the women also resists going out. Married women or women with a partner engaging in leisure activities alone are easily regarded as being dissatisfied with the status quo of life, whether this represents dissatisfaction with family life, with their husband, or even with their sex life, coupled with the possible suggestion that they are looking for opportunities for an affair. Thus, women are unwilling to engage in leisure activities alone in public areas. Most of the partners in the beginning will agree to allow women to go out for sports and leisure, but once women actively participate in leisure in public spaces, they are often stricken by their partner's complaints.

\section{Women's Leisure Opportunities and Provisions}

Women's performances in leisure and entertainment organisations, institutions, and groups are passive compared to men's, and they seldom speak out or enter the power core. This phenomenon highlights the fact that women find currently available leisure facilities to be in line with their expectations, expressing their support and positive attitudes. Sometimes women will want to seek equality with men in games with the rules formulated by men. In this context, there are two conditions. First, women are to establish a group that belongs exclusively to women. The second is to involve more women to strengthen the influence on existing groups, and even to provide women with enough power and control (Tsai, 2010b). However, mainstream values of society deem that it is not easy for women to be influential in the group unless they perform better in the group, provide more positive suggestions, and do not blindly succumb to men in the organisation. Only then may they access the advantageous status in the mainstream. A Filipina respondent described her leisure experiences before and after coming to Taiwan in the following manner:

I have more leisure opportunities after coming to Taiwan, because previously in the Philippines I had very little budget to use for leisure, so I had no means for any leisure. Now that I am helping others do cleaning work, I feel I have a decent income, so sometimes I stroll to the night market. I like to watch Taiwan's cultural performances, but the programmes are never introduced in foreign languages. I hope the organisers can prepare a simple description, let me know more about Taiwan, and also provide more leisure choices. Otherwise, I can only go to church.There were differences in the understanding of space distribution for leisure and the supply of facilities and configuration between both genders. Male leisure and entertainment industries try to establish space for women's use, but women feel that these facilities are unfriendly and 
indifferent and cannot connect with their lives (Dunstan et al., 2010; Bopp \& Kaczynski, 2010). A Thai respondent expressed her feelings as follows:

I prefer to make a date with single friends to go out for fun or visit the pub, but sometimes I do not like the eyes of the bar staff on women.

Regarding the types of leisure facilities and institutions which provide leisure facilities, the leisure supply for women has gradually improved. Some women also attempt to break the limitations of social class and gender (Rossman \& Schlatter, 2011). In the past, in order for organisations, agencies, and groups to provide leisure and entertainment, most elements of decision making were dominated by men, such as provisions for use of the clubs and the rights and interests to be enjoyed by both genders (Monika \& Santos, 2006). Various positions of empowerment are often preferred to be undertaken by men, and women are continuously excluded in employment and reward for fear of women gaining power or interest. When the ratio of women participating in public meetings is too low, the sense of their existence is lesser, and they rarely speak out in the important groups or on issues that may be of interest to them. This may affect women's positions of power in the organisations or groups.

\section{Conclusions: Cross-National Understanding of Female Foreign Workers' Leisure}

The number of foreign workers in Taiwan is increasing, and their leisure activities after work have become a strong area of research on work and leisure. The findings of this research will not only contribute to the formation of public and private leisure provisions and the management of female foreign workers, but will also fill the gap in research related to 'work and leisure.' The main problem in conducting this international comparative study is the language factor, and the same difficulty applies to the data collection of foreign workers from Indonesia, Cambodia, and Thailand. To overcome the language barrier, this study sought assistance from foreign worker consultants who specifically received within the Labour Department the county's and city government's complaint calls from foreign workers in order to conduct interview visits. Every county has at least four foreign worker consultants with expertise in different languages. Filipino workers have fewer language barriers, as theirs are based on English. As to the Vietnamese women migrant workers, many are 'ethnic Chinese' who can speak Chinese; Vietnamese graduate students in Taiwan were also invited to assist in the interviews. In order to ensure the progress of the concept of leisure for both genders, the placement of feminism in leisure policies is very important. Policies must turn theory into consistent and explanatory reality. The development, implementation, monitoring, and evaluation of the policies render relevant social and cultural theory provisions of leisure to be complied with; thus, improving the current 
situation is a considerable benefit. Although demands for gender equality and related policy making began three centuries ago, the beneficiaries of the use of recreational public areas are now those residents of Taiwan who are usually engaged in sports and leisure. The policies which are planned and promoted for ethnic groups who usually do not participate in leisure activities (e.g. females, minority ethnic groups, working class people) should not be overlooked either.

Although foreign periodicals are not lacking in their analysis of foreign worker leisure issues, this is nearly the first attempt in the analysis of leisure activities under cross-nationalism for advanced countries (U.S., Canada, and U.K.) and developing countries (The Philippines, Thailand, Vietnam, Indonesia, Cambodia) by means of cross-country comparisons. In the study of female foreign workers' leisure activities in Taiwan, this paper functions as a pioneer of sorts. In the past, the analytical study of female foreign workers' labour and leisure was practically nonexistent in Taiwan. Therefore, the systematic and specific comparison analysis and discussion of female foreign workers' leisure theory and practical operation is helpful in closing this academic gap. The conclusions and findings comprise further contributions to the knowledge system and theory of Taiwan's leisure, labour, and human resources management. In recent years, Taiwan has been rated by the U.S. State Department as a human trafficking country, making Taiwan's international labour rights an issue of concern. As a result, in the Council of Labour Affairs or the labour department of the local county government, the organisation of foreign workers' leisure activities has been taken up as a key policy. However, female foreign workers' and male foreign workers' leisure needs are different. At the same time, the leisure models of foreign workers from different countries differ, and work arrangements also affect the choice of leisure opportunities for female foreign workers. Therefore, the analysis and results of this study will help the government to carry out more meticulous planning when formulating and organising foreign workers' leisure activities, will assist in sorting out potential problems of foreign workers regarding living counselling and adaptation, and will contribute to the formulation of foreign workers' leisure policies.

\section{REFERENCES}

Baxter, L., Hughes, C., \&Tight, M. (1996). How to Research. Buckingham: Open University Press.

Bopp, M., \& Kaczynski, A. T. (2010). Leisure and becoming physically active. In L. Payne, G. Godbey, \& B. Ainsworth (eds.), Leisure, Health and Wellness: Making The Connection, pp. 133-146. State College, PA: Venture Publishing, Inc. 
Chang L., \& Chang, C. M. (2007). The relationship study on role conflict and leisure constraint in married employee women. Journal of Leisure and Tourism Industry Research, 2(1), 68-79 (In Chinese).

Chiang, A. C (2006). The "Demonstration effect" in a dual economy. The American Journal of Economics and Sociology, 18(3), 249. http://dx.doi.org/10.1111/j.1536-7150.1959.tb00321.x

Chiao, C. K. (2005). A study on the international labor standards concerning the protection of the rights of foreign domestic workers. Socioeconomic Law and Institution Review, 35, 147-180 (In Chinese).

Chou, C. H., Chen, S. H., \&Chang, Z. L. (2007). Sociology of Leisure. Taipei: Hua-Li Publisher (In Chinese).

Chung, C. C., Hsiao, J., Pan, W. H., \& Chung, H. W. (2008). A study of leisure participation, job involvement and job satisfaction of amusement parks employees. Journal of Sport and Recreation Research, 2(3), 21-36 (In Chinese).

Council of Labor Affairs of the Executive Yuan (2007). Foreign Workers Management and Utilization Survey. Taipei: Council of Labor Affairs of the Executive Yuan (In Chinese).

Council of Labor Affairs of the Executive Yuan (2010). The 2010 Employment Security Fund. Taipei: Bureau of Employment and Vocational Training, Council of Labour Affairs (In Chinese).

Dunstan, D. W., Healy, G. N., Sugiyama, T., \& Owen, N. (2010). 'Too much sitting' and metabolic risk-has modern technology caught up with us? European Endocrinology, 6(1), 19-23.

Edginton, C. R. \& Coles, R. (2009). World Leisure Organization - Leisure: Enhancing the Human Condition Priorities \& Strategies 2009-2014. Cedar Falls, IA: World Leisure Organization.

Edginton, C. R., Chin, M. K., Geadelmann, P., \& Ahrabi-Fard, I. (2011). Global forum for physical education pedagogy 2010 (GoFPEP 2010): Health and physical education pedagogy in the 21st century - A statement of consensus. International Journal of Physical Education, 48(2), 33-41.

Field, A. E., Gorfon, C. M., Pierce, L. M., \& Kocher, M.S. (2011). Prospective study of physical activity and risk of developing a stress fracture among preadolescent and adolescent girls. Archives of Pediatrics \& Adolescent Medicine, 165(8), 723-728. http://dx.doi.org/10.1001/archpediatrics.2011.34

Hsin, P. L. (2007). Foreign labor employment and the effect of helping local labors. Employment Security, 6(2), 22-26 (In Chinese). 
Hsu, H. Y. (2006). Human right and policy: The case of Kaohsiung MRT Foreign workers’ campaign. Taiwan Law Journal, 83, 81-87 (In Chinese).

Jiang, F. F. (2006). Impacts of foreign worker importation on the unemployment, occupational choice and wage rates of local workers. Taiwan Economic Forecast and Policy, 37(1), 69-111 (In Chinese).

Karp, I., Barnett, T. A., O'Loughlin, J., Sabiston, C. M., Bélanger, M., Van Hulst, A., \& Lambert, M. (2010). Teens and screens: The influence of screen time on adiposity in adolescents. American Journal of Epidemiology, 172(3), 255-262. http://dx.doi.org/10.1093/aje/kwq125

Kimmel, A. (1988). Ethics and Values in Applied Social Research. CA: Newsbury Park, Sage.

Lan, P. C. (2002). A transnational topography for the migration and identification of filipina migrant domestic workers. Taiwan: A Radical Quarterly in Social Studies, 48, 169-218 (In Chinese).

Lan, P. C. (2006). Legal servitude and free illegality: Control and exit of migrant workers. Taiwan: A Radical Quarterly in Social Studies, 64, 107-150 (In Chinese).

Lin, C. J. (2000). The state policy that divides women: Rethinking feminist critiques to "the foreign maid policy" in Taiwan. Taiwan: A Radical Quarterly in Social Studies, 39, 93-152 (In Chinese).

Lin, W. G., \& Lin, H. F. (2008). Research of Vietnamese female foreign workers' experience during fleeing. Police Science Quarterly, 38(5), 73-94 (In Chinese).

Liu, M. C. (2001). Working time struggle: A critique from political economy. Bulletin of Labour Research, 10, 23-52 (In Chinese).

Monika, S. \& Santos, C. (2006). Transnationalism and Leisure: Mexican Temporary Migrants in the U.S. Journal of Leisure Research, 38(2), 143-167.

Neulinger, J. (1981). To Leisure: An Introduction. Boston: Allyn and Bacon.

Parker, S. (1983). Leisure \& Work. London: George \& Unwin.

Payne, L., Ainsworth, B., \& Godbey, G. (2010). Leisure, Health and Wellness: Making the Connection. State College, PA: Venture Publishing, Inc.

Rossman, J. R., \& Schlatter, B. E. (2011). Recreation Programming Designing and Staging Leisure Experiences (6th Ed.). Champaign, IL: Sagamore.

Soong, J. J., \& Su, C. P. (2008). Overview of human rights of foreign labor policy in Taiwan. Parliament Journal, 36(2), 7-23 (In Chinese).

Tsai, C. L. (2006). The influence of Confucianism on women's leisure in Taiwan. Leisure Studies, 25 (4), 469-476. 
Tsai, C. L. (2008). A mapping of women's participation in leisure: illustrations from the case study of UK. Journal of Leisure and Recreation Industry Management, $1(2), 1-12$.

Tsai, C. L. (2009). Media systems and their effects on women's sport participation in Taiwan. Sport, Education and Society, 14(1), 37-53.

Tsai, C. L. (2010a). The power game: Cultural influences on gender and leisure. World Leisure Journal, 52(2), 148-156.

Tsai, C. L. (2010b). A reflection on cultural conflicts in women's leisure. Leisure Sciences, 32(4), 386-390.

Tseng, Y. F. (2004). Expressing nationalist politics in guest worker program: Taiwan's recruitment of foreign labor. Taiwanese Journal of Sociology, 32, 1-58 (In Chinese).

United States Department of State (2007). Trafficking in Persons Report. 2010/06/24, retrieved from http://www.ait.org.tw/zh/officialtext-ot0710.html

United States Department of State (2010). Trafficking in Persons Report. 2010/06/24, retrieved from http://www.ait.org.tw/zh/officialtext-ot1017.html

Van Domelen, D. R., Koster, A., Caserotti, P., Brychta, R. J., Chen,K. Y., McClain, J. J., Troiano, R. P., Berrigan, D., \& Harris, T. B. (2011). Employment and physical activity in the US. American Journal of Preventive Medicine, 41(2), 136-145. http://dx.doi.org/10.1016/j.amepre.2011.03.019.

Wang, H. R., \& Juan, H. J. (2007). The labor right and life conselling of foreign factory workers. Employment Security, 6(2), 27-32 (In Chinese).

Wu, S. C. (2006). The trapped labor: An analysis of the working conditions and employee-employer relations of foreign domestic workers and the examination of foreign labor policies in Taiwan. Social Policy \& Social Work, 10(2), 1-48 (In Chinese).

$\mathrm{Wu}, \mathrm{T} . \mathrm{F}$. (2002). The resistance and adaptation of foreign workers in Taiwan in the 1990s. Hong Kong Journal of Social Science, 23, 103-150.

Wu, Y. J. (2008). Report of Job Security and Policy: The Administration and Management of Foreign labors. Chiayi: National Chung Cheng University Press (In Chinese).

Yang, X., Telama, R., Hirvensalo, M., Hintsanen, M., Hintsa, T., Pulkki-Råback , L., \& Viikari, J.S. (2010). The benefits of sustained leisure-time physical activity on job strain. Occupational Medicine, 60(5), 369-375. http://dx.doi.org/ 10.1093/occmed/kqq019 
Yeh, T. C. (2008). Relationship between leisure identity and leisure behavior among university faculties-Case study in a northern Taiwan university. Journal of Sport and Recreation Research, 2(3), 150-164 (In Chinese). 
